\title{
DETERMINATION OF CONGESTION CHARGE FOR CAR USERS IN CBD AREA OF THIRUVANANTHAPURAM CITY
}

\author{
Tina Maria Sunny ${ }^{1}$, Jomy Thomas ${ }^{2}$ \\ ${ }^{I}$ M. Tech scholar, Transportation Engineering, RIT, Kottayam, Kerala, India, tinamariasunny@gmail.com \\ ${ }^{2}$ Asst.Professor, RIT Kottayam, Kottayam, Kerala, India, jomythomas04@yahoo.com
}

\begin{abstract}
Congestion is a situation in which demand for road space exceeds supply and is characterized by slower speeds, longer trip times, higher transportation costs and increased vehicular queuing. Thiruvananthapuram, the capital city of Kerala, is the second largest and most populous city in the state.The roads and neighbourhoods of the city experiences more chronic congestion and serious crashes than ever before due to higher share of personalized transport and para-transit modes in traffic stream. The present study conducted in Central Business District (CBD) area of Thiruvananthapuram city. The periods of peak congestion in Thiruvananthapuram now last for 4 hours from 8.00 to 10.00 in the morning and from 4.00 to 6.00 in the evening. In this paper, an attempt has been made to assess the congestion level experienced on major road corridors of the city and to determine congestion charge for car users in Mahatma Gandhi Road, which is the most congested road corridor of Thiruvanathapuram city. The method used for the determination of optimal pricing is related to the point of pricing where the external costs are met by the revenue generated by the pricing level.
\end{abstract}

Keywords: Congestion pricing, External costs of congestion, Travel time, Demand elasticity.

\section{INTRODUCTION}

Congestion is a situation in which demand for road space exceeds supply. A combination of population growth, urbanization and increasing economic prosperity has led to significant congestion problems in many parts of the world, particularly in the urban areas. Congestion has many negative impacts such as delays, higher transportation costs, increased travel time etc. All these undesirable traffic characteristics increase the level of air pollution and noise, wear and tear of vehicles, and poor operational efficiencies. Widening roads and providing additional new roads became the mechanism to provide additional capacity to deal with growth of traffic. Today, limited opportunity to add more roads or widen existing roads has added to more traffic congestion.

Congestion pricing or road pricing is a system that directly charges the motorists for the use of a road or a network of roads. The level of congestion-pricing depends upon the extent of the area under consideration and time. As the traffic rises the capacity of a road, each additional vehicle imposes delay on others resulting in economically excessive traffic volumes. Vehicle users both bear and impose congestion costs. Congestion costs will be different for each road and even for a single road, it could be constantly changing depending on the demand for use of the road at particular time. The fundamental objective of the study was to estimate an optimum congestion charge for car users on the congested corridor of Thiruvananthapuram city. Booming economy, aspirations to own a car, mismatched public transport with respect to demand or comfort or both and the government's encouraging policies such as open car market, easy loan schemes etc. are a few reasons for increasing private modes at a rapid rate in the city. Higher share of personalized transport and para-transit modes in traffic stream were the primary causes of traffic congestion in the city.

\section{OBJECTIVES OF STUDY}

Objectives of the study included,

- To assess the extent of traffic congestion prevailing in the study area by analyzing a congestion performance measure.

- Identification of the most congested corridor of Thiruvananthapuram city.

- To determine an optimum congestion charge for car users which includes costs of delays, wasted fuel, and environmental costs.

\section{LITERATURE REVIEW}

In order to achieve a clear knowledge in the field of congestion pricing and external costs of congestion, a literature review was performed. Large numbers of studies have been conducted globally for deterrmining the optimum congestion charge for different vehicle classes.

Bijit et al (2009) analysed the traffic congestion experienced in Sylhet city. To assess the severity of the existing traffic system engulfed by tremendous traffic congestion they estimated a roadway congestion index and it was obtained as 2.36 indicated the severity of traffic congestion in Sylhet city. The authors also recommended some solutions for efficient traffic management in Sylhet city. 
Sarkar et al (2009) conducted study on traffic congestion and congestion pricing in Central Business District (CBD) of New Delhi. The authors made an attempt to determine the cost of congestion in central area of Delhi that is Connaught Place with a view to ensuring desired Level of Service. To assess the present nature and traffic characteristics of the study area, basic analysis was carried out with respect to traffic and travel characteristics. The external cost of congestion for road users was calculated and then through demand elasticity curves, the level of pricing required was identified.

Larson et al (2010) explained that drivers in urban neighbourhoods who using roads causes traffic congestion by parking vehicles on street. The authors studied the two alternatives for implementing congestion pricing scheme: road pricing, which involves cordoning off a section of the center city and imposing a fee on all vehicles that enter it; and parking pricing, which increases the costs of on-street. They proposed a queuing model to estimate the number of cruising drivers and the optimal parking price by conducting a study at Boston-area.

Tanzila Khan et al (2013) estimated the cost of traffic congestion in Dhaka City. The authors calculated travel time costs using value of time approach and vehicle operating cost due to traffic congestion directly along with allowances for travel time variability, delay externality, dead-weight losses and cost of excess fuel burnt due to congestion. The total annual cost due to traffic congestion in Dhaka was obtained as about USD 3868 million per annum.

Alexander et al (2013) discussed on road pollution exposure as an externality of traffic, particularly during the time of traffic congestion when on-road pollution exposure was highest. The authors developed marginal private and external cost equations that include on-road pollution exposure in addition to time, fuel, and pollution emissions components.. A sensitivity analysis was done and the results shows that on-road pollution exposure has a large portion of about $18 \%$ of marginal social costs of traffic flow near freeway capacity, ranging from $4 \%$ to $38 \%$ with different exposure parameters

The method adopted in the study to determine the optimum congestion charge is to identify the point of pricing where the external costs are met by the revenue generated by the pricing level. Different methods for the estimation of external costs of congestion were also reviewed.

\section{RESEARCH METHODOLOGY}

Methodology includes review of earlier projects, selection of route stretches in the study area, data collection, data analysis and estimation of congestion charge for car users on the congested corridor. Six main road corridors of Thiruvananthapuram city were selected for the study.

Data collection was done by primary and secondary survey. Primary data collection include traffic and road characteristics survey and willingness to pay survey.
Secondary data was collected from National Transportation Planning and Research Centre (NATPAC), Thiruvanathapuram. The data collected were analysed to determine the congestion level on the selected road stretches and to identify the most congested corridor. The external costs related to congestion such as travel time cost, fuel cost and pollution cost of car users were estimated. To arrive at an optimum congestion charge the point of intersection of external cost curve and demand elasticity curve for cars was identified and the pricing fee was estimated.

\section{DATA COLLECTION}

\section{A. Study Area}

Six major road corridors selected for the study are PMG-Sreekaryam, PMG-Sasthamangalam, VellayambalamPeroorkada, LMS-Attakulangara, Over BridgePappanamcode and Palayam - Chakai.

Figure 1 shows the Map of Thiruvananthapuram city with selected road stretches. Details of the road sections are shown in the Table I.

Table I: Selected routes with their details

\begin{tabular}{|c|l|c|l|}
\hline $\begin{array}{c}\text { Sl. } \\
\text { No }\end{array}$ & \multicolumn{1}{|c|}{ Route } & $\begin{array}{c}\text { Length } \\
(\mathbf{k m})\end{array}$ & \multicolumn{1}{c|}{ Designation } \\
\hline 1. & $\begin{array}{l}\text { PMG- } \\
\text { Sreekaryam }\end{array}$ & 7.1 & $\begin{array}{l}\text { Salem-Kochi-Kanyakumari } \\
\text { Highway }\end{array}$ \\
\hline 2. & $\begin{array}{l}\text { PMG- } \\
\text { Sasthamangalam }\end{array}$ & 3.6 & - \\
\hline 3 & $\begin{array}{l}\text { Vellayambalam- } \\
\text { Peroorkada }\end{array}$ & 4 & $\begin{array}{l}\text { Thiruvananthapuram-Ponmudi } \\
\text { road }\end{array}$ \\
\hline 4 & $\begin{array}{l}\text { Overbridge- } \\
\text { Pappanamcode }\end{array}$ & 5.1 & $\begin{array}{l}\text { Salem-Kochi-Kanyakumari } \\
\text { Highway }\end{array}$ \\
\hline 5 & $\begin{array}{l}\text { Palayam- } \\
\text { Chakai }\end{array}$ & 3.98 & $\begin{array}{l}\text { Attakulangara- } \\
\text { LMS }\end{array}$ \\
\hline
\end{tabular}

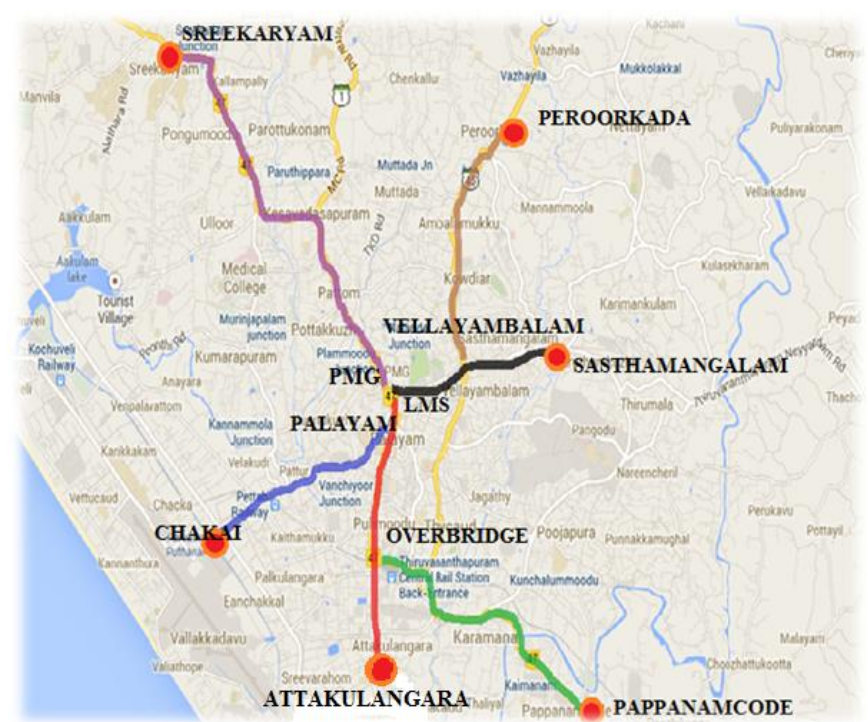

Figure 1. Map of Thiruvananthapuram city with selected road stretches 


\section{B. Road Inventory Details}

Geometric characteristics including pavement width, curvature, roughness, rise and fall of the six study stretches were collected to determine the free flow travel speed of these routes.

\section{Traffic characteristics data}

Moving car-observer method was used to determine the journey speed and delays. The six selected road corridors were divided into different sections and test runs were made on these sections during peak and off-peak hours of the day. The time required for travel between each sections of the route was noted by using a stopwatch. Delay incurred during the time of travel between each section was also noted to determine the peak hour travel speed. The extent of variation of traffic flow on the most congested corridor was ascertained by carrying out the twelve-hour weekday volume count.

\section{Secondary Data}

To quantify the value of travel time of car users of Thiruvanathapuram city 14 wards around the study area were selected. The average monthly income of the sampled size of $\mathrm{f}_{\text {. }}$ car users from these wards were collected from NATPAC.

\section{E. Opinion Survey}

The opinion and views of car users on Mahatma Gandhi Road about congestion pricing have been gathered through a questionnaire survey. A sample of persons were interviewed from various public and private firms and shopping centres located between Palayam and East Fort. Travel information details like origin, destination, and time of travel, frequency of travel and the purposes of the trip were collected. Commuter's opinion about the ease of driving and level of congestion on their travel routes were also gathered. The commuter's response to the proposal for the introduction of a congestion pricing scheme and the amount of congestion charge they are willing to pay was elicited. Out of 800 car users interviewed $61.75 \%$ are willing to pay charge, while $38.25 \%$ of them are not willing to pay the congestion charge. The commuter's response to the amount of congestion charge they are willing to pay was used for plotting the demand elasticity curve. The demand elasticity curve for car users plotted from the opinion survey is shown in Figure 2.

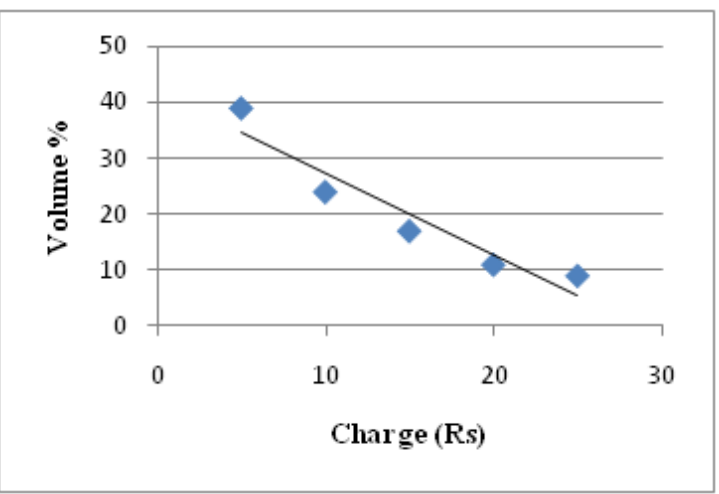

Figure 2. Demand elasticity curve for cars users

\section{DATA ANALYSIS AND RESULTS}

Data collected from primary and secondary surveys were analysed. The analysis of the survey data was made for three basic purposes.

i) Determination of congestion level of the selected road corridors.

ii) Quantification of external costs of congestion.

iii) Estimation of optimum congestion charge for car users of the most congested corridor.

The congestion level of each of the six stretches was assessed and the most congested corridor of Thiruvananthapuram city was identified. The external cost including travel time cost, pollution cost and fuel cost of car users of the congested corridor was calculated for a peak daily volume of traffic. The coefficients of Bureau of Public Roads (BPR) model for travel time data were calibrated and validated using SPSS (Statistical Packages for Social Sciences) software. The variation of external cost and demand elasticity curve for car users were plotted and the congestion charge for them for the most congested corridor was estimated.

Congestion level determination of road corridors

The traffic congestion level of the selected road stretches of Thiruvananthapuram city were assessed by estimating a congestion performance measure named travel time index.

$$
\text { Travel Time Index }=\frac{\text { Free flow travel speed }}{\text { Peak hour travel speed }}
$$

Peak hour travel speed of cars through different sections of road corridor was estimated by dividing the length of section to the time taken for travel including delay during peak time. The free flow speed of cars in $\mathrm{km} / \mathrm{hr}$ was determined using the equation recommended by Kadiyali (1981),

Free flow speed of cars in $\mathrm{km} / \mathrm{hr}$ is,

$$
\begin{gathered}
\mathrm{V}_{\mathrm{C}}=52.4202+1.7609 \mathrm{~W}-0.1621 \mathrm{RS}-0.1240 \mathrm{FL}- \\
0.0123 \mathrm{CV}-0.0025 \mathrm{RG}
\end{gathered}
$$

Where,

$$
\begin{aligned}
& \mathrm{W}=\text { Pavement width in } \mathrm{m} \\
& \mathrm{RS}=\text { Rise in } \mathrm{m} / \mathrm{km} \\
& \mathrm{FL}=\text { Fall in } \mathrm{m} / \mathrm{km} \\
& \mathrm{CV}=\text { Curvature degrees } / \mathrm{km} \\
& \mathrm{RG}=\text { Roughness in } \mathrm{mm} / \mathrm{km}
\end{aligned}
$$

Table II: Travel time index value of selected road corridors

\begin{tabular}{|c|l|c|c|c|}
\hline $\begin{array}{c}\text { Sl. } \\
\text { No }\end{array}$ & \multicolumn{1}{|c|}{ Road corridors } & $\begin{array}{c}\text { Peak } \\
\text { hour } \\
\text { speed } \\
(\mathrm{km} / \mathrm{hr})\end{array}$ & $\begin{array}{c}\text { Free } \\
\text { flow } \\
\text { speed } \\
(\mathrm{km} / \mathrm{hr})\end{array}$ & $\begin{array}{c}\text { Travel } \\
\text { time } \\
\text { index }\end{array}$ \\
\hline 1 & PMG - Sreekaryam & 20.77 & 63.37 & 3.05 \\
\hline 2 & PMG - Sasthamangalam & 29.88 & 72.4 & 2.42 \\
\hline 3 & Vellayambalam -Peroorkada & 29.31 & 70.03 & 2.39 \\
\hline 4 & Overbridge - Pappanamcode & 23.77 & 66.96 & 2.82 \\
\hline 5 & Palayam - Chakai & 21.32 & 66.7 & 3.13 \\
\hline 6 & Attakulangara - LMS & 16.42 & 4.45 & 4.45 \\
\hline
\end{tabular}


Mahatma Gandhi road, which is the major travel corridor passing through the Central Business District (CBD) area of Thiruvananthapuram was identified the most congested corridor. The travel time index value of M.G. Road is 4.45; while the other road stretches have the index value less than 4. Table II shows the computed travel time index value of the six study stretch.

ii. Estimation of external costs of congestion

Mahatma Gandhi road is the main arterial road in Thiruvananthapuram city. A section of M.G road from LMS to Attakulangara of length about $3.38 \mathrm{~km}$ was selected for the estimation of external costs related to congestion. The main wholesale business district of the city, Chalai Bazaar is situated here. Important landmarks of the city like the Kerala Government Secretariat housing various government offices, Kerala University, Padmanabha Swamy Temple and Pazhavangadi temple are located on this stretch. The City Bus Stand is also located along this road. The hourly traffic volume of MG road for a peak day used for the analysis of external cost of congestion was given in Table III and Figure 3.

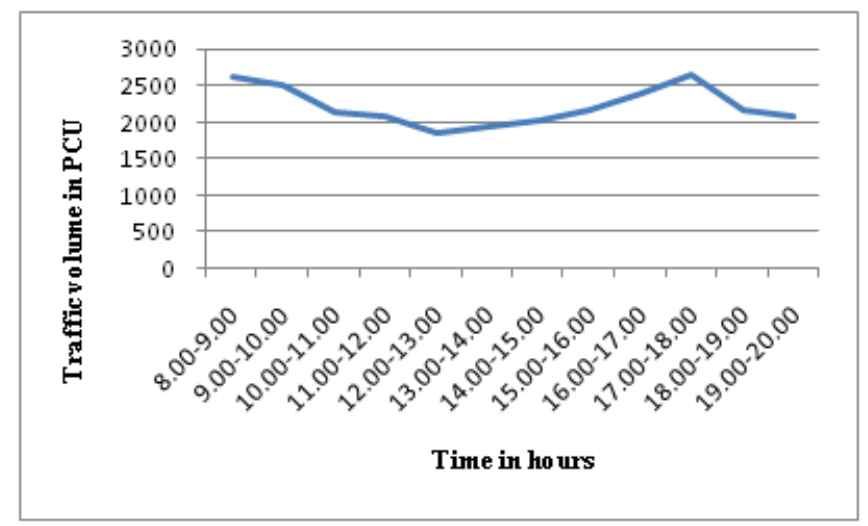

Figure 3. Hourly traffic volume of M.G Road in PCU

The volume - capacity ratios of traffic for each hours of the day were determined by taking the capacity of the study stretch as 1450 vehicles per hour per lane from IRC: $106-$ 1990 for 4 lane road. The flow of traffic through both directions of this route was almost equal and the periods of peak congestion in M.G Road last for 4 hours from 8.00 to 10.00 in the morning and from 4.00 to 6.00 in the evening. During that time of day V/C ratio of traffic is more than 1.5. It indicates the extremely severe traffic congestion experienced by M.G Road. During these times of the day traffic volume (PCU) is greater than 2500 and volume of cars is generally more compared to the volume of other vehicle classes. So it was decided to conduct the study on proposed congestion charge during this period of the day. Cars were the main contributors to traffic congestion during this time compared to other type of vehicles. It was decided to estimate an optimum congestion charge for cars users only.

\section{1) Travel Time Cost}

As a result of congestion, an extra road user adds to the travel times of other vehicles. This causes a travel time cost to the road user. Travel time cost is estimated by using the following equation.

Travel time cost $=$ Value of travel time for car users $\mathrm{xTraffic}$ volume $\mathrm{x}$ Occupancy of car $\mathrm{x}$ Travel time taken for travelling through the entire route

As per IRC: SP $30-1993$, the occupancy of car was taken as 2.3 and value of travel time for car users of Thiruvanathapuram city was estimated by wage rate approach as Rs.102.93 per hour.

\section{2) Fuel Cost}

Fuel consumption of a vehicle along a route depends on many factors such as the speed of vehicle, type of the road surface and its roughness, vertical profile of road, vehicle and fuel characteristics etc. Fuel cost of cars is estimated using the equaton specified by IRC.

According to IRC: SP 30-1993,

Fuel cost $=$ Cost of fuel (Rs./liter) $x$ Fuel Consumption (liters)

Fuel consumption (liters/1000 km),

$$
\begin{aligned}
& \mathrm{FC}=21.85+(504.15 / \mathrm{V})+\left(0.004957 \times \mathrm{V}^{2}\right)+ \\
& 0.000652 \mathrm{RG}+1.0684 \mathrm{RS}-0.3684 \mathrm{FL}
\end{aligned}
$$

Where,

$$
\begin{aligned}
& \mathrm{V}=\text { Speed of vehicle in } \mathrm{km} / \mathrm{hr} \\
& \mathrm{RG}=\text { Roughness in } \mathrm{mm} / \mathrm{km} \\
& \mathrm{RS}=\text { Rise in } \mathrm{m} / \mathrm{km} \\
& \mathrm{FL}=\text { Fall in } \mathrm{m} / \mathrm{km},
\end{aligned}
$$

Average roughness, rise and fall of M.G Road were 2665.8 $\mathrm{mm} / \mathrm{km}, 7.96 \mathrm{~m} / \mathrm{km}$ and $5.45 \mathrm{~m} / \mathrm{km}$ respectively. Cost of petrol and diesel were taken as Rs.75 and Rs. 60 per liters.

\section{3) Pollution Cost}

Major pollutants such as $\mathrm{CO}, \mathrm{NO}_{\mathrm{X}}, \mathrm{SO}_{2}$, and particulate matters from cars were considered for the estimation of pollution cost from the point of view of road user cost and his health. Table IV shows the emission factors of pollutants adopted for the study.

Pollution cost $=$ Traffic volume $\mathrm{x}$ Distance $\mathrm{x}$ Emission factors of pollutants $\mathrm{x}$ Value of cost of pollution

The value for cost of pollution was considered as 7.22 Rs per $\mathrm{kg}$ as recommended by Aditi Singh and P.K. Sarkar (2009). and distance of the section was taken as $3.38 \mathrm{~km}$.

Table IV: Emission factors of major pollutants adopted for study

\begin{tabular}{|c|c|c|}
\hline $\begin{array}{c}\text { Sl. } \\
\text { No }\end{array}$ & Pollutants & $\begin{array}{c}\text { Emission } \\
\text { Factors }(\mathrm{g} / \mathrm{km})\end{array}$ \\
\hline 1 & $\mathrm{CO}$ & 1.98 \\
\hline 2 & $\mathrm{NO}_{\mathrm{X}}$ & 0.2 \\
\hline 3 & $\mathrm{SO}_{2}$ & 0.05 \\
\hline 4 & Particulate matter & 0.03 \\
\hline
\end{tabular}

(Source: Transport Fuel Quality for the year 2005, Central Pollution Control Board) 
The total travel time cost, fuel cost and pollution cost estimated for car users per hour on M.G road were summed up and divided by the respective volume to compute the external cost per car user. The existing total cost of car users on M.G Road for each hours of the day is shown in Table V.The external cost per car user per $\mathrm{km}$ for peak hours ( 8.00 am to 10 am and $4.00 \mathrm{pm}$ to $6.00 \mathrm{pm}$ ) of a day is shown in Table VI. It was used for plotting the external cost curve for car users.

iii. Estimation of congestion charge for car users

\section{1) Calibration of BUREAU OF PUBLIC ROAD (BPR) model for travel time}

Bureau of Public Road has been the traditional method for predicting vehicle speed and travel time as a function of volume-capacity ratio in travel demand models. The data used for the calibration of model was the time taken by car user to travel through the selected section (LMS Attakulangara) of M.G road.The data was obtained from NATPAC, which was taken by moving car observer method. Non-linear regression technique was used for the analysis of the model. The calibration of the model was done using SPSS20 software package.

BPR function for travel time is,

$$
\begin{gathered}
\mathrm{T}=\mathrm{T}_{\mathrm{o}}\left[1+\mathrm{a}(\mathrm{X})^{\mathrm{b}}\right] \\
\text { Where, } \\
\mathrm{T}=\text { average link travel time. } \\
\text { To = free-flow link travel time. } \\
\mathrm{X}=\text { volume to capacity ratio. } \\
\text { a and b are parameters }
\end{gathered}
$$

\begin{tabular}{|c|c|c|c|c|c|c|c|c|c|c|c|c|c|c|}
\hline \multirow[b]{2}{*}{$\begin{array}{l}\text { Sl. } \\
\text { No }\end{array}$} & \multirow[b]{2}{*}{$\begin{array}{l}\text { Time } \\
\text { (hrs) }\end{array}$} & \multirow{2}{*}{$\begin{array}{l}\text { Traffic } \\
\text { volume } \\
\text { (cars) }\end{array}$} & \multirow{2}{*}{$\begin{array}{c}\text { Speed } \\
(\mathrm{km} / \mathrm{hr})\end{array}$} & \multicolumn{2}{|c|}{ Value of time } & \multicolumn{6}{|c|}{ Pollution Emissions } & \multicolumn{2}{|c|}{$\begin{array}{c}\begin{array}{c}\text { Fuel consumption } \\
\text { (litres) }\end{array} \\
\end{array}$} & \multirow[b]{2}{*}{$\begin{array}{l}\text { Total } \\
\text { cost } \\
\text { (Rs) }\end{array}$} \\
\hline & & & & $\begin{array}{l}\text { Total } \\
\text { time } \\
\text { spend } \\
\text { (hours) }\end{array}$ & $\begin{array}{c}\text { Total } \\
\text { Travel } \\
\text { time cost } \\
(\mathrm{Rs})\end{array}$ & $\begin{array}{l}\mathrm{CO} \\
(\mathrm{kg})\end{array}$ & $\begin{array}{l}\text { NOx } \\
(\mathrm{kg})\end{array}$ & $\begin{array}{l}\mathrm{SO}_{2} \\
(\mathrm{~kg})\end{array}$ & $\begin{array}{l}\mathrm{PM} \\
(\mathrm{kg})\end{array}$ & $\begin{array}{l}\text { Total } \\
(\mathrm{kg})\end{array}$ & $\begin{array}{c}\text { Total } \\
\text { Pollution } \\
\text { cost } \\
\text { (Rs.) }\end{array}$ & $\begin{array}{c}\text { Total fuel } \\
\text { consumpt } \\
\text { ion } \\
\text { (litres) }\end{array}$ & $\begin{array}{c}\text { Total fuel } \\
\text { cost } \\
\text { (Rs) }\end{array}$ & \\
\hline 1 & $8.00-9.00$ & 485 & 17.42 & 284.34 & 29267.21 & 3.25 & 0.33 & 0.08 & 0.05 & 3.70 & 26.75 & 99.23 & 6623.38 & 35917.34 \\
\hline 2 & $9.00-10.00$ & 497 & 16.08 & 271.83 & 27979.38 & 3.33 & 0.34 & 0.08 & 0.05 & 3.80 & 27.41 & 105.36 & $\begin{array}{l}7032.74 \\
\end{array}$ & 35039.53 \\
\hline 3 & $10.00-11.00$ & 426 & 19.13 & 192.63 & 19827.27 & 2.85 & 0.29 & 0.07 & 0.04 & 3.25 & 23.49 & 83.88 & 5598.79 & 25449.55 \\
\hline 4 & $11.00-12.00$ & 368 & 32.86 & 125.78 & 12946.02 & 2.46 & 0.25 & 0.06 & 0.04 & 2.81 & 20.30 & 65.66 & 4382.74 & 17349.06 \\
\hline 7 & $14.00-15.00$ & 321 & 38.62 & 108.87 & 11205.92 & 2.15 & 0.22 & 0.05 & 0.03 & 2.45 & 17.70 & 56.99 & 3804.04 & 15027.66 \\
\hline 8 & $15.00-16.00$ & 345 & 28.73 & 155.84 & 16040.22 & 2.31 & 0.23 & 0.06 & 0.03 & 2.64 & 19.03 & 62.65 & 4182.16 & 20241.41 \\
\hline 9 & $16.00-17.00$ & 440 & 16.91 & 217.88 & 22426.76 & 2.94 & 0.30 & 0.07 & 0.04 & 3.36 & 24.27 & 91.19 & 6086.87 & 28537.9 \\
\hline 10 & $17.00-18.00$ & 473 & 16.25 & 271.00 & 27893.61 & 3.17 & 0.32 & 0.08 & 0.05 & 3.61 & 26.09 & 99.79 & 6661.03 & 34580.73 \\
\hline 11 & $18.00-19.00$ & 432 & 19.28 & 218.39 & 22479.22 & 2.89 & 0.29 & 0.07 & 0.04 & 3.30 & 23.83 & 84.80 & 5660.44 & 28163.49 \\
\hline 12 & $19.00-20.00$ & 397 & 32.73 & 158.15 & 16278.27 & 2.66 & 0.27 & 0.07 & 0.04 & 3.03 & 21.90 & 68.16 & 4549.96 & 20850.13 \\
\hline
\end{tabular}

Table III: Hourly traffic volume in PCU and volume/capacity ratio

\begin{tabular}{|c|c|c|c|c|c|c|c|c|c|c|c|c|}
\hline Sl. No & \multicolumn{2}{|c|}{ Time } & Car & $\mathbf{3 W}$ & $\mathbf{2 W}$ & Bus & LCV & Goods & Truck & Cycle & PCU & V/C \\
\hline 1 & 8.00 & 9.00 & 485 & 315 & 431 & 415 & 4 & 8 & 3 & 2 & 2618 & 1.81 \\
\hline 2 & 9.00 & 10.00 & 497 & 308 & 425 & 381 & 6 & 11 & 2 & 4 & 2499 & 1.72 \\
\hline 3 & 10.00 & 11.00 & 396 & 294 & 387 & 324 & 2 & 3 & 2 & 6 & 2133 & 1.47 \\
\hline 4 & 11.00 & 12.00 & 368 & 316 & 378 & 312 & 3 & 4 & 1 & 4 & 2072 & 1.43 \\
\hline 5 & 12.00 & 1.00 & 293 & 291 & 388 & 276 & 4 & 4 & 3 & 2 & 1857 & 1.28 \\
\hline 6 & 1.00 & 2.00 & 358 & 247 & 321 & 304 & 6 & 12 & 0 & 4 & 1945 & 1.34 \\
\hline 7 & 2.00 & 3.00 & 321 & 286 & 354 & 323 & 0 & 3 & 0 & 4 & 2016 & 1.39 \\
\hline 8 & 3.00 & 4.00 & 345 & 254 & 382 & 356 & 0 & 6 & 0 & 1 & 2159 & 1.49 \\
\hline 9 & 4.00 & 5.00 & 440 & 421 & 419 & 339 & 6 & 17 & 4 & 0 & 2383 & 1.64 \\
\hline 10 & 5.00 & 6.00 & 473 & 342 & 457 & 412 & 2 & 12 & 4 & 3 & 2641 & 1.82 \\
\hline 11 & 6.00 & 7.00 & 402 & 323 & 432 & 319 & 5 & 2 & 0 & 3 & 2175 & 1.50 \\
\hline 12 & 7.00 & 8.00 & 397 & 252 & 373 & 324 & 3 & 3 & 4 & 0 & 2093 & 1.44 \\
\hline Total & & & $\mathbf{4 7 7 5}$ & $\mathbf{3 6 4 8}$ & $\mathbf{4 7 4 7}$ & $\mathbf{4 0 8 5}$ & $\mathbf{4 1}$ & $\mathbf{8 5}$ & $\mathbf{2 3}$ & $\mathbf{3 3}$ & $\mathbf{2 6 5 9 2}$ & $\mathbf{1 . 5 3}$ \\
\hline
\end{tabular}

Table V: Existing total cost of car users for each hours of the day

Table VI: External cost per km per car user for peak hours of the day

\begin{tabular}{|c|c|c|c|c|c|c|}
\hline $\begin{array}{c}\text { Sl. } \\
\text { No }\end{array}$ & $\begin{array}{c}\text { Time } \\
\text { (hrs) }\end{array}$ & $\begin{array}{c}\text { Travel time } \\
\text { cost(Rs) }\end{array}$ & $\begin{array}{c}\text { Pollution } \\
\text { cost (Rs.) }\end{array}$ & Fuel cost (Rs) & Total Cost (Rs) & $\begin{array}{c}\text { External cost } \\
(\text { Rs per km) }\end{array}$ \\
\hline 1 & $8.00-9.00$ & 29267.21 & 26.75 & 6623.38 & 35917.34 & 21.91 \\
\hline 2 & $9.00-10.00$ & 27979.38 & 27.41 & 7032.74 & 35039.53 & 20.86 \\
\hline 3 & $16.00-17.00$ & 22426.76 & 24.27 & 6086.87 & 28537.90 & 19.19 \\
\hline 4 & $17.00-18.00$ & 27893.61 & 26.09 & 6661.03 & 34580.73 & 21.63 \\
\hline Total & & $\mathbf{1 0 7 5 6 6 . 9 6}$ & $\mathbf{1 0 4 . 5 1}$ & $\mathbf{2 6 4 0 4 . 0 3}$ & $\mathbf{1 3 4 0 7 5 . 5 0}$ & $\mathbf{2 0 . 9 0}$ \\
\hline
\end{tabular}


100 samples of travel time and volume data were collected. Out of this 80 data points were used for the calibration of model and the remaining 20 samples were held out for validation. Free flow speed for MG Road i.e., $73.03 \mathrm{~km} / \mathrm{hr}$ already obtained from the previous analysis was used to determine the free flow link travel time and it was obtained as $0.0463 \mathrm{hr}$. After calibrating the model using SPSS software, the values for parameters ' $a$ ' and ' $b$ ' were obtained. The obtained values of coefficients of the model are shown in Table VII.

Table VII: Values obtained for the coefficients of BPR model

\begin{tabular}{|c|c|c|}
\hline Parameter & Value & $\begin{array}{c}\text { Standard error of the } \\
\text { estimate }\end{array}$ \\
\hline $\mathbf{a}$ & 0.902 & 0.083 \\
\hline $\mathbf{b}$ & 2.537 & 0.179 \\
\hline
\end{tabular}

The BPR function for travel time was obtained as

$\mathrm{T}=0.0463\left[1+0.902(\mathrm{x})^{2.537}\right]$

The overall model fit is deemed reasonable since $\mathrm{R}^{2}=0.743$ which means $74.3 \%$ of the variance of the dependent variables can be explained by the model.

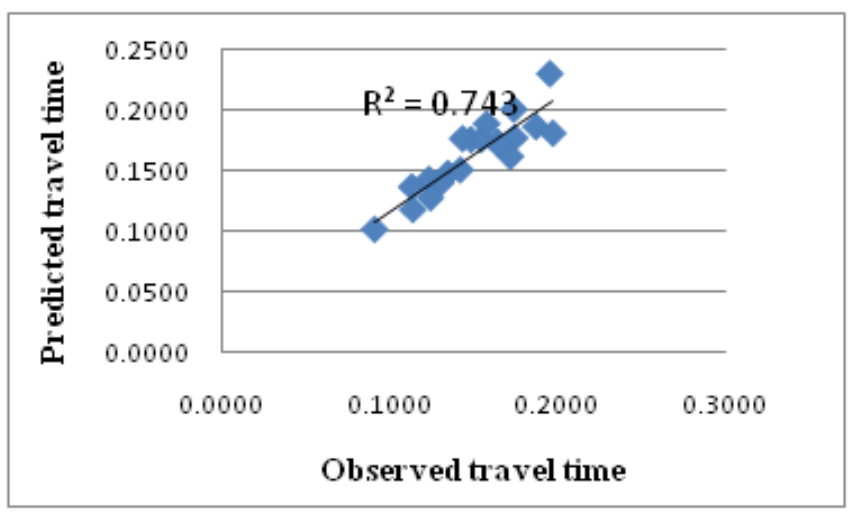

Figure 4. Goodness of fit of BPR model

Model validation was done by checking Mean Absolute Percentage Error (MAPE) method.

$$
\begin{gathered}
\text { MAPE }=\frac{100}{\mathrm{n}} \sum\left|\frac{\mathrm{Oi}-\mathrm{Ei}}{\mathrm{Oi}}\right| \\
\text { where, } \\
\mathrm{n}=\text { Number of observations } \\
\mathrm{Oi}=\text { Observed value } \\
\mathrm{Ei}=\text { Theoretical value }
\end{gathered}
$$

According to Lewis' scale of interpretation of estimation accuracy (Kenneth and Ronald, 1982), any forecast with a MAPE value of less than $10 \%$ can be considered highly accurate, $11 \%-20 \%$ as good, $21 \%-50 \%$ as reasonable and $51 \%$ or more as inaccurate. Mean percentage absolute error obtained for the above model was $12.00 \%$. Thus the result obtained was good with MAPE less than $20 \%$.

\section{2) Determination of optimum congestion charge}

For plotting the external cost curve, volume of cars for 4 peak hours of the existing traffic were taken and various volumes of cars were assumed in the descending order.
These volumes of cars were divided by 4 to convert it into hourly volume. It was assumed that the volume of cars only decreased during peak hours, while the volume of other type of vehicle classes remains same. For estimating volume capacity ratios, the volume of other vehicle classes corresponding to the peak hourly volume of cars for the existing traffic was used. The hourly volume of vehicle classes adopted for the analysis is shown in Table VIII. The BPR model developed was used for the determination of travel time and average speed for the obtained values of volume- capacity ratios. Table IX shows the travel time and speed estimated using BPR model.

TABLE VIII: Volume of vehicle classes used for analysis

\begin{tabular}{|l|c|c|l|l|l|l|l|}
\hline $\begin{array}{l}\text { Vehicle } \\
\text { class }\end{array}$ & $\begin{array}{c}3 \\
\text { W }\end{array}$ & $\begin{array}{c}2 \\
\text { W }\end{array}$ & Bus & LCV & $\begin{array}{l}\text { Goods } \\
\text { auto }\end{array}$ & Cycle & Truck \\
\hline $\begin{array}{c}\text { Hourly } \\
\text { volume }\end{array}$ & 308 & 425 & 381 & 6 & 11 & 2 & 4 \\
\hline
\end{tabular}

Using the obtained values of speed and travel time and the equations (3), (4) and (5) travel time cost, fuel cost and pollution cost were estimated respectively for the new volume of cars. The variation of external cost with volume of cars are tabulated in Table X.

The method adopted for the determination of optimal congestion charge is to identify the point of pricing where the external costs are met by the revenue generated by the pricing level. This relationship when seen along with the demand elasticity of the traffic with respect to pricing gives a level of traffic where the external costs generated by the traffic would be equal to the acceptable charge enforced. This relationship is shown in Figure 5.

Mahatma Gandhi Road, which is the major travel corridor passing through the Central Business District (CBD) area $f$ thiruvananthapuram has the highest travel time index value of 4.45. To arrive at an optimum congestion charge, external cost curve and demand elasticity curve for cars were plotted. The demand elasticity of the traffic with respect to pricing gives a level of traffic where the external costs generated by the traffic would be equal to the acceptable charge enforced was identified as Rs 14.50 per kilometre. So it was accepted as the pricing fee for congestion charging of car users.

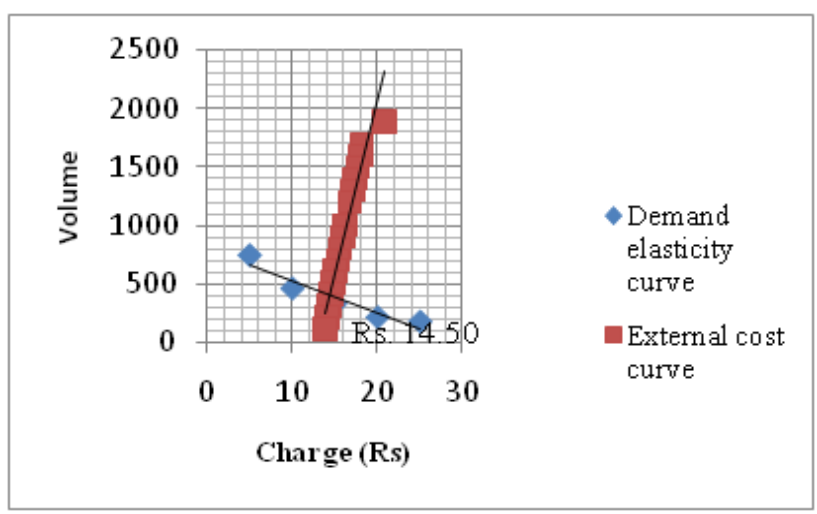

Figure 5. External cost curve and demand elasticity curve for cars 
TABLE IX: Travel time and speed estimated using BPR model

\begin{tabular}{|c|c|c|c|c|c|}
\hline Volume of cars for 4 hours of a day & Hourly volume of cars & PCU & V/C & Travel time (hr) & Speed (km/hr) \\
\hline 1700 & 425 & 2427 & 1.67 & 0.2003 & 16.87 \\
\hline 1600 & 400 & 2402 & 1.66 & 0.1985 & 17.03 \\
\hline 1500 & 375 & 2377 & 1.64 & 0.1945 & 17.38 \\
\hline 1400 & 350 & 2352 & 1.62 & 0.1905 & 17.75 \\
\hline 1300 & 325 & 2327 & 1.61 & 0.1865 & 18.12 \\
\hline 1200 & 300 & 2302 & 1.59 & 0.1827 & 18.50 \\
\hline 1000 & 250 & 2252 & 1.55 & 0.1751 & 19.30 \\
\hline 900 & 225 & 2227 & 1.54 & 0.1715 & 19.71 \\
\hline 800 & 200 & 2202 & 1.52 & 0.1679 & 20.14 \\
\hline 700 & 175 & 2177 & 1.50 & 0.1643 & 20.57 \\
\hline 600 & 150 & 2152 & 1.48 & 0.1608 & 21.01 \\
\hline 500 & 125 & 2127 & 1.47 & 0.1574 & 21.47 \\
\hline 400 & 100 & 2102 & 1.45 & 0.1541 & 21.94 \\
\hline 300 & 75 & 2077 & 1.43 & 0.1508 & 22.41 \\
\hline 200 & 50 & 2052 & 1.42 & 0.1476 & 22.90 \\
\hline 100 & 25 & 2027 & 1.40 & 0.1444 & 23.40 \\
\hline
\end{tabular}

TABLE X: Variation of external cost with volume of cars

\begin{tabular}{|c|c|c|c|c|c|c|}
\hline S1. No & Volume of cars & Travel time cost (Rs) & Pollution cost (Rs.) & Fuel cost (Rs.) & Total cost $(\mathrm{Rs})$ & $\begin{array}{c}\text { External cost } \\
\text { (Rs per km) }\end{array}$ \\
\hline 1 & 1895 & 107566.96 & 104.51 & 26404.03 & 134075.50 & 20.90 \\
\hline 2 & 1700 & 80617.48 & 93.76 & 23539.83 & 104251.1 & 18.14 \\
\hline 3 & 1600 & 75197.52 & 88.24 & 22068.02 & 97353.78 & 18.00 \\
\hline 4 & 1500 & 69053.90 & 82.73 & 20504.09 & 89640.72 & 17.68 \\
\hline 5 & 1400 & 63125.10 & 77.21 & 18968.84 & 82171.15 & 17.36 \\
\hline 6 & 1300 & 57406.21 & 71.70 & 17461.43 & 74939.34 & 17.05 \\
\hline 7 & 1200 & 51892.35 & 66.18 & 15981.02 & 67939.55 & 16.75 \\
\hline 8 & 1000 & 41460.46 & 55.15 & 13097.69 & 54613.3 & 16.16 \\
\hline 9 & 900 & 36532.88 & 49.64 & 11693.04 & 48275.56 & 15.87 \\
\hline 10 & 800 & 31791.25 & 44.12 & 10311.89 & 42147.26 & 15.59 \\
\hline 11 & 700 & 27230.89 & 38.61 & 8953.36 & 36222.86 & 15.31 \\
\hline 12 & 600 & 22847.17 & 33.09 & 7616.54 & 30496.8 & 15.04 \\
\hline 13 & 500 & 18635.50 & 27.58 & 6300.54 & 24963.62 & 14.77 \\
\hline 14 & 400 & 14591.32 & 22.06 & 5004.42 & 19617.8 & 14.51 \\
\hline 15 & 300 & 10710.13 & 16.55 & 3727.25 & 14453.93 & 14.25 \\
\hline 16 & 200 & 6987.46 & 11.03 & 2468.102 & 9466.59 & 14.00 \\
\hline 17 & 100 & 3418.88 & 5.52 & 1226.008 & 4650.41 & 13.76 \\
\hline
\end{tabular}


The study reveals that the value of travel time for car user was quite substantial. For car users, it was estimated to be of around of Rs 102.93 per hour. The study also reveals that the willingness to pay congestion charge by car users is also quite significant. $24 \%$ of car users are willing pay Rs 10 while $17 \%$ of car users are willing to pay Rs 15 and $11 \%$ of car users are willing to pay Rs 20 .

\section{CONCLUSIONS}

To assess the extent of traffic congestion prevailing in the study area and to identify the routes of Thiruvananthapuram where congestion pricing was required a detailed study of the six main road corridors of city was conducted. A congestion performance measure named travel time index was estimated for the existing traffic of seleced road corridors and the congestion level of these study stretches were identified. It was revealed that the Mahatma Gandhi road corridor between Attakulangara and LMS, which is the major travel corridor passing through the Central Business District (CBD) area of Thiruvananthapuram has the highest travel time index value of 4.45 , indicating the severity of traffic congestion problems faced by this road. The congestion price for car users obtained is Rs 14.50 per kilometer. The study reveals that the value of travel time for car user was quite substantial. For car users, it was estimated to be of around of Rs 102.93 per hour. The study also reveals that the willingness to pay congestion charge by car users is also quite significant. $24 \%$ of car users are willing pay Rs 10 while $17 \%$ of car users are willing to pay Rs 15 and $11 \%$ of car users are willing to pay than Rs 20 . The result from the opinion survey was used to plot the demand elasticity curve for car users.

\section{ACKNOWLEDGMENT}

The authors would like to thank Dr.T.Elankovan, Head, Traffic and Transportation Division , National Transportation Planning and Research Centre (NATPAC), Thiruvanathapuram for the valuable comments and recommendations. In addition, the authors would like to thank the NATPAC staffs especially to Mr.Ebin Sam and Mr. Aneesh (Scientist B) for providing valuable suggestions throughout the project.And also thanks to NATPAC for providing not only the facilities for conducting surveys also the data sets.

\section{REFERENCES}

[1] Alam, M.A., Ahmed, F., (2013). "Urban transport systems and congestion: A case study of Indian cities". Transport and Communications Bulletin for Asia and the Pacific No. 82.

[2] Banik, B.K., Chowdhury, A.I., Alam Sarkar, S.K., (2009). "Study of traffic congestion in Sylhet city." Journal of Indian Road Congress, 550, 75-86.

[3] Bigazzi, A. Y., and Figliozzi, M. A. (2013). "Marginal costs of freeway traffic congestion with on-road pollution exposure externality." Transportation Research Part A, $57,12-24$.

[4] CPCB (Central Pollution Control Board), Transport Fuel Quality for the year 2005. Probes/78/2000-01.New Delhi; 2000 .
[5] EEA (European Environment Agency). Joint EMEP/CORINAIR Atmospheric Emission Inventory Guidebook. Third ed. Copenhagen: European Environment Agency; 2001.

[6] Gonzalez-Guzman, C.A., and Robuste, F., (2011). "Road space reallocation according to car congestion externality." Journal of Urban Planning and Development, 137(3).

[7] Hansen, I., (2001). "Determination and evaluation of traffic congestion costs". European Journal of Transport and Infrastructure Research, 1, 61-72.

[8] Hong K. L., and Hickman, M.D., (1997). "Toward an evaluation framework for road pricing." Journal of Transportation Engineering, 123(4).

[9] IRC, Guidelines for capacity of urban roads in plain areas. (1990). IRC: 106. New Delhi.

[10] IRC, Manual on economic evaluation of Highway projects in India. (1993). IRC SP: 30. New Delhi.

[11]Johansson, O., (1997). "Optimal road-pricing: Simultaneous treatment of time losses, increased fuel consumption, and emissions." Transportation Research Part D, 2, 77-87.

[12] Kadiyali, L.R., (2000). Traffic Engineering and Transportation planning, Khanna Publishers, New Delhi.

[13] Kenneth, D. L., and Ronald, K. K. (1982). Advances in business and management forecasting. Emerald books, U.K.

[14] Khan, T., Islam, R., (2013). "Estimating costs of traffic congestion in Dhaka City". International Journal of Engineering Science and Innovative Technology, 2(3), 281-289.

[15]Larson., Richard, C., Saanuama., and Katsunobu., (2010). "Urban vehicle congestion pricing - A review." Journal of Industrial and Systems Engineering, 3(4), 227-242.

[16]Litman, T., (2011). "London Congestion Pricing Implications for other Cities." Victoria Transport Policy Institute.

[17] Maitra B., Sikdar, P. K., and Dhingra, S. L., (2004). "Modeling of congestion: A tool for urban traffic management in developing countries." Journal of European Transport, 27, 45-56.

[18] Mittal, M.L., Sharma, C., (2003). "Anthropogenic emissions from energy activities in India: generation and source characterization (Part II: Emissions from vehicular transport in India).

[19]Rao, A. M., and Rao, K.R., (2012). "Measuring urban traffic congestion - A review." International Journal for Traffic and Transport Engineering, 2(4), 286 - 305.

[20] Singh, A., and Sarkar, P. K. (2009). "Determination of congestion cost in Central Business District of New Delhi - A case study." Journal of Indian Road Congress, 552, 130-14. 